\title{
PENGARUH KONSUMSI JUS JAMBU TERHADAP KADAR HEMOGLOBIN PADA MAHASISWI ASRAMA MAMBA'UL ULUM SURAKARTA
}

\author{
Sri Iswahyuni1, Sri Sayekti Heni Sunaryanti2 \\ STIKES Mamba'ul 'Ulum Surakarta \\ (iswahyunisri@yahoo.co.id)
}

\begin{abstract}
ABSTRAK
Latar belakang :anemia merupakan penyakit akibat kurangnya sel darah merah. Pada mahasiswi/remaja perempuan sering mengalami anemia karena peningkatan kebutuan sel darah merah untuk pertumbuhan dan kehilangan darah karena mentruasi setiap bulan. Anemia pada remaja perempuan dapat berdampak panjang untuk dirinya dan juga untuk anak yang ia lahirkan kelak. Sel darah merah tersusun atas hemoglobin, yang berperan penting dalam mendukung fungsi darah sebagai Anemia karena kekurangan zat besi dipengaruhi juga oleh vitamin C. Jambu biji merupakan buah yang banyak mengandung antioksidan, seperti likopen, vitamin $\mathrm{C}$ dan pectin. Vitamin $C$ dan pectin.Penelitian ini bertujuan untuk mengetahui pengaruh konsumsi jus jambu biji terhadap kadar hemoglobin pada mahasiswi asrama Mamba'ul 'Ulum Surakarta.

Metode :Penelitian ini adalah penelitian analitik eksperimental dengan desainPretes-postest with Control.Populasi penelitian ini adalah mahasiswi asrama Mamba'ul 'Ulum Surakarta. Sampel di tentukan dengan purposisive sampling diperoleh sejumlah 26 mahasiswa. Metode pengumpulan data dengan kuisioner dan pemeriksaan hemoglobin sebelum dan sesudah pemberian jus jambu biji merah pada kelompok perlakuan dan pemberian sirup rendah gula pada kelompok kontrol. Hasil :ada pengaruh konsumsi jus jambu biji merah dengan korelasi sebesar 0,922 dengan signifikansi 0,000. Karena signifikansi $<0,05$ maka dapat disimpulkan terdapat hubungan yang signifikan antara kadar Hemoglobin sebelum dan sesudah pemberian jus jambu biji merah. Dari rata-rata (mean) diketahui bahwa rata-rata kadar hemoglobin mahasiswi setelah pemberian jus jambu lebih tinggi daripada sebelum pemberian jus jambu.
\end{abstract}

Kesimpulan : pemberian jus jambu dapat meningkatkan kadar hemoglobin mahasiswi warga Asrama Mahasiswa Mamba'ul ‘Ulum Surakarta.

Kata kunci : Pengaruh, Jus jambu biji merah, Hemoglobin.

\section{ABSTRACT}

Background: anemia is a disease caused by lack of red blood cells. Female students often sustain anemia due to an increase in the need for red blood cells for the growth and loss of blood due to menstruation every month. Anemia in adolescent girls can have a long -term impact on her and also for the child she is born with. The red blood cells are composed of hemoglobin, which plays an important role in supporting the functioning of blood as an agent of oxygen and carbon dioxide transport to or from the tissues. Hemoglobin is a protein rich in iron. Iron deficiency affects blood hemoglobin levels. Anemia due to iron deficiency is also affected by vitamin C. Guava is a fruit that contains many 
antioxidants, such as lycopene, vitamin $C$ and pectin. This study aimed to determine the effect of guava juice consumption on hemoglobin level in female students at Mamba'ul 'Ulum Surakarta.

Method: This research was an experimental analytic research with Pretespostest with Control design. The population of this study were female students of Mamba'ul 'Ulum Surakarta. The samples were determined by purposive sampling which was obtained by 26 students. Methods of data collection were with questionnaires and hemoglobin examination before and after guava juice treatment in the treatment group and administration of low-sugar syrup in the control group.

Result: there was influence of red guava juice consumption with correlation equal to 0.922 with significance 0.000. Because of significance $<0.05$ it could be concluded that there was a significant relationship between hemoglobin levels before and after guava juice. From the mean (average) was known that the average hemoglobin level of female students after giving guava juice was higher than before having guava juice.

Conclusion: the giving of guava juice can increase the hemoglobin level of female students of Mamba'ul 'Ulum Surakarta Student Dormitory.

Keywords: Influence, Guava Juice, Hemoglobin.

\section{PENDAHULUAN}

Anemia merupakan penyakit akibat kurangnya sel darah merah.Sel darah merah tersusun atas hemoglobin, yang berperan penting dalam mendukung fungsi darah sebagai pelaku transportasi oksigen dan karbondioksida ke atau dari jaringan. Hemoglobin ialah protein yang kaya akan zat besi. Kekurangan zat besi akan mempengaruhi kadar hemoglobin darah (Muhilal, 2004).

Pada mahasiswi/remaja perempuan sering mengalami anemia karena peningkatan kebutuan sel darah merah untuk pertumbuhan dan kehilangan darah karena mentruasi setiap bulan. Anemia pada remaja perempuan dapat berdampak panjang untuk dirinya dan juga untuk anak yang ia lahirkan kelak

Anemia defisiensi besi merupakan anemia yang terbanyak baik di Negara maju maupun Negara yang sedang berkembang. Padahal besi merupakan suatu unsur terbanyak pada lapisan kulit bumi, akan tetapi defisiensi besi merupakan penyebab anemia yang tersering. Hal ini disebabkan tubuh manusia mempunyai kemampuan terbatas untuk menyerap besi dan seringkali tubuh mengalami kehilangan besi yang berlebihan yang diakibatkan perdarahan (Hoffbrand et al, 2005). Anemia karena kekurangan zat besi dipengaruhi juga oleh vitamin C.Vitamin $C$ berfungsi mereduksi besi ferri $(\mathrm{Fe} 3+)$ menjadi ferro ( $\mathrm{Fe} 2+)$ dalam usus halus sehingga mudah diabsorpsi.Vitamin $\mathrm{C}$ juga menghambat pembentukan hemosiderin yang sulit dimobilisasi untuk membebaskan zat besi bila diperlukan oleh tubuh.Absorpsi zat besi dalam bentuk non heme meningkat 
empat kali lipat bila ada vitamin C.Vitamin C berperan dalam memindahkan zat besi dari transferin di dalam plasma ke ferritin hati.Sebagian besar transferin darah membawa zat besi ke sumsum tulang dan bagian tubuh lainnya.Di dalam sumsum tulang zat besi digunakan untuk membentuk hemoglobin (Almatsier, 2001). Menurut Hoffbrand et al. (2005), sumsum tulang memerlukan prekursor seperti zat besi, vitamin C, vitamin B12, kobalt dan hormon untuk pembentukan sel darah merah dan hemoglobin.

Psidium guajava L. atau sering biasa kita sebut jambu biji ini merupakan tanaman yang berasal dari Amerika Serikat Tengah, lalu penyebaran tanaman ini meluas ke kawasan Asia Tenggara dan ke wilayah Indonesia melalui Thailand (Cahyono, 2010). Jambu biji merupakan buah yang banyak mengandung antioksidan, seperti likopen, vitamin C dan pectin.Vitamin C dan pectin. Asrama Mahasiswa Mamba'ul 'Ulum Surakarta merupakan kumpulan mahasiswi yang tinggal di asrama dimana mempunyai jenis kelamin dan aktivitas yang dilakukan sama, sehingga dapat dikendalikan saat penelitian dilaksanakan. Berdasarkan latar belakang tersebut peneliti tertarik untuk meneliti "Pengaruh Konsumsi Jus Buah Jambu Biji Terhadap Kadar Hemoglobin pada Mahasiswi di Asrama Mahasiswa Mamba'ul 'Ulum Surakarta”.

\section{METODE PENELITIAN}

Penelitian ini adalah penelitian analitik eksperimental dengan desainPretes-postest with Control.Waktu penelitian ini dilakukan DesemberPebruari 2018. Tempat penelitian ini dilakukan di asrama Mamba'ul 'Ulum Surakarta.Subyek pada penelitian ini adalah Mahasiswi di Asrama Mamba'ul 'Ulum Surakarta yang berusia 17-19 tahun.Obyek dari penelitian ini adalah hasil pemeriksaan Hemoglobin.

Populasi penelitian ini adalah mahasiswi asrama Mamba'ul 'Ulum Surakarta Sampel di tentukan dengan purposisive sampling diperoleh sejumlah 26 mahasiswa.Sampel di bagi menjadi 2 kelompok yaitu kelompok perlakuan yang diberikan jus jambu biji merah, dan kelompok kontrol yang tidak mengkonsumsi jus jambu biji tetapi diberi sirup rendah gula Metode pengumpulan data dengan kuisioner dan pemeriksaan hemoglobin sebelum dan sesudah pemberian jus jambu biji merah pada kelompok perlakuan dan pemberian sirup rendah gula pada kelompok kontrol.

\section{HASIL DAN PEMBAHASAN}

Penelitian diawali dengan permohonan ijin kepada Kepala Asrama Mahasiswa Mamba'ul 'Ulum Surakarta dan setelah ini diterima oleh peneliti dilanjutkan dengan sosialisasi dan pemberian surat persetujuan menjadi sampel serta kuesioner kepada populasi warga Asrama mahasiswa Mamba'ul 'Ulum Surakarta. Berdasarkan sosialisasi didapatkan 26 responden 
yang lolos kriteria.Responden yang didapatkan peneliti dibagi 2 kelompok, yaitu kelompok perlakuan sebanyak 13 responden dan kelompok control sebnyak 13 responden.

Sampel yang dididapatkan oleh peneliti dalam penlitian ini tidak banyak, hanya 26 sampel, hal ini di sebabkan karena ketatnya kriteria sampel antara lain : mahasiswi di asrama Mamba'ul 'Ulum Surakarta yang masih melakukan kegiatan diarea asrama dan kampus saja, bersedia menjadi responden penelitian dengan menandatangani surat persetujuan tindakan medis, usia 17-19 tahun, tidak melakukan aktifitas berat, tidak merokok dalam waktu 12 minggu sebelumnya, tidak mengkonsumsi alkohol dalam waktu 30 tahun terakhit, tidak mengkonsumsi obat-obatan dan atau suplemen, tidak sedang mentruasi selama pelaksanaan penelitian ( 8 hari), berjenis kelamin perempuan, nilai BMI dalam batas normal >_18,5 $-<22,9$.

Tabel 1.Hasil Pemeriksaan Kadar Hemoglobin pada Mahasiswi Kelompok Perlakuan dan Kelompok Kontrol di Asrama Mahasiswa Mamba'ul ‘Ulum Surakarta.

\begin{tabular}{lllccll}
\hline \multicolumn{7}{c}{ Kadar Hemoglobin (mg/dl) } \\
\hline NO & SAMPEL & KELOMPOK & SEBELUM & SESUDAH & SELISIH & KESIMPULA \\
& & & & & & N \\
1 & S1 & PERLAKUAN & 10,4 & 11,0 & 0,6 & Meningkat \\
2 & S2 & PERLAKUAN & 10,5 & 11,8 & 1,3 & Meningkat \\
3. & S3 & PERLAKUAN & 12,4 & 12,4 & 0 & Tetap \\
4. & S4 & PERLAKUAN & 10,5 & 11,5 & 1,0 & Meningkat \\
5 & S5 & PERLAKUAN & 11,0 & 11,9 & 0,9 & Meningkat \\
6. & S6 & PERLAKUAN & 10,9 & 11,8 & 0,9 & Meningkat \\
7. & S7 & PERLAKUAN & 9,6 & 9,7 & 0,1 & Meningkat \\
8. & S8 & PERLAKUAN & 8,3 & 8,6 & 0,3 & Meningkat \\
9. & S9 & PERLAKUAN & 12,8 & 12,9 & 0,1 & Meningkat \\
10. & S10 & PERLAKUAN & 10,0 & 11,5 & 1,5 & Meningkat \\
11. & S11 & PERLAKUAN & 10,3 & 11,00 & 0,7 & Meningkat \\
12. & S12 & PERLAKUAN & 11,0 & 12,00 & 1,0 & Meningkat \\
13. & S13 & PERLAKUAN & 12,00 & 12,9 & 0,9 & Meningkat \\
14. & K1 & KONTROL & 11,2 & 11,1 & $-0,1$ & Menurun \\
15. & K2 & KONTROL & 11,4 & 9,1 & $-2,3$ & Menurun \\
16. & K3 & KONTROL & 10,6 & 10,8 & 0,2 & Meningkat \\
17. & K4 & KONTROL & 9,0 & 9,1 & 0,1 & Meningkat \\
18. & K5 & KONTROL & 13,6 & 9,3 & $-4,3$ & Menurun \\
19. & K6 & KONTROL & 13,1 & 12,4 & $-0,7$ & Menurun \\
20. & K7 & KONTROL & 12,3 & 11,6 & $-0,7$ & Menurun \\
21. & K8 & KONTROL & 12,5 & 13,1 & 0,6 & Meningkat \\
22. & K9 & KONTROL & 10,0 & 9,7 & $-0,3$ & Menurun \\
23. & K10 & KONTROL & 13,4 & 11,4 & -2 & Menurun \\
24. & K11 & KONTROL & 11,00 & 11,01 & 0,01 & Meningkat \\
25. & K12 & KONTROL & $11,412,0$ & 11,04 & $-0,36$ & Menurun \\
26. & K13 & KONTROL & 0 & 12,01 & 0,01 & Meningkat \\
\hline & & & & & &
\end{tabular}

Keterangan : S (kelompok perlakuan / jus jambu biji)

K (kelompok kontrol / sirup) 
a. Analisa data statistik pada kelompok perlakuan (diberi jus jambu) Table 2.Paired Samples Statistics pada sampel dengan perlakuan (diberi jus jambu)

\begin{tabular}{lllrrr}
\hline & Mean & N & Std. Deviation & Std. Error Mean \\
\hline \multirow{2}{*}{ Pair 1 } & sebelum & 10.7462 & 13 & 1.18927 & .32984 \\
\cline { 2 - 6 } & sesudah & 11.4615 & 13 & 1.20591 & .33446 \\
\hline
\end{tabular}

Dari hasil uji analisis statistik pada sampel dengan perlakuan di beri jus jambu sehari 3 kali adalah rata-rata hasil pemeriksaan hemoglobin sebelum diberi jus jambu adalah 10.7462, jumlah sampel data 13, standar deviasi 1.18927, dan standar error mean 0.32984. Sedangkan untuk sesudah perlakuan pemberian jus jambu adalah mean 11.4615 dengan jumlah sampel 13, standar deviasi 1.20591 dan standar error mean 0.33446 .

Tabel 3.Paired Sampel Korelasi pada sampel dengan perlakuan (diberi jus jambu)

\begin{tabular}{|c|c|c|c|c|}
\hline \multicolumn{5}{|c|}{ Paired Samples Correlations } \\
\hline & & $\mathrm{N}$ & Correlation & Sig. \\
\hline Pair 1 & sebelum \& sesudah & 13 & .922 & .000 \\
\hline
\end{tabular}

Pada tabel 6 tersebut menunjukkan besarnya korelasi atau hubungan antara dua sampel sebelum dan sesudah pemberian jus jambu.Berdasarkan hasil uji korelasi tersebut menunjukkan Signifikansi (sig) $<0,05$, maka terdapat hubungan yang signifikan antara sebelum dan sesudah pemberian jus jambu. Diketahui nilai korelasi sebesar 0,922 dengan signifikansi 0,000. Karena signifikansi $<0,05$ maka dapat disimpulkan terdapat hubungan yang signifikan antara kada Hemoglobil sebelum dan sesudah pemberian jus jambu.

Jika nilai korelasi semakin mendekati 1, maka hubungannya semakin kuat.Sedangkan jika nilai korelasinya semakin medekati 0 , maka hubungannya semakin lemah (Priyono, 2012).Jadi karena nilai korelasi 0,922 (semakin mendekati 1) maka hubungan yang terjadi adalah kuat.

Tabel 4. Paired Samples T Test pada sampel dengan perlakuan (diberi jus jambu)

Paired Samples Test

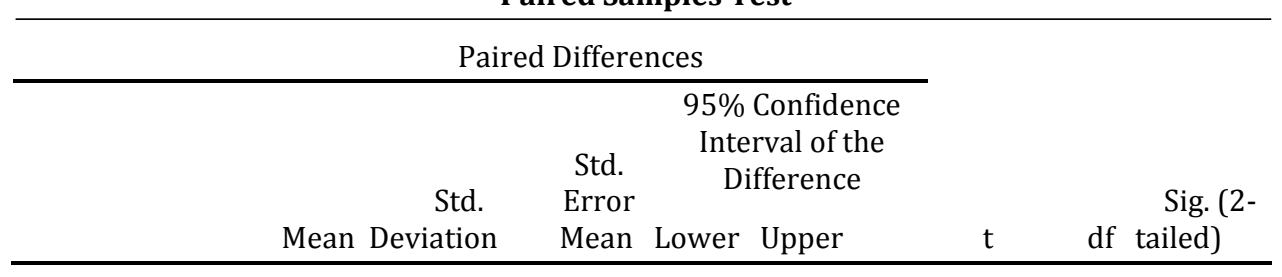


Paired Samples Test

\begin{tabular}{|c|c|c|c|c|c|c|c|}
\hline \multicolumn{5}{|c|}{ Paired Differences } & \multirow[b]{3}{*}{$\mathrm{t}$} & \multirow[b]{3}{*}{ df } & \multirow{3}{*}{$\begin{array}{l}\text { Sig. (2- } \\
\text { tailed) }\end{array}$} \\
\hline & & $\begin{array}{l}\text { Std. } \\
\text { Error }\end{array}$ & $\begin{array}{l}95 \% \text { Conf } \\
\text { Interval } \\
\text { Differe }\end{array}$ & $\begin{array}{l}\text { fidence } \\
\text { of the } \\
\text { ence }\end{array}$ & & & \\
\hline Mean & Deviation & Mean & Lower & Upper & & & \\
\hline $\begin{array}{l}\text { Pair } 1 \text { sebelum -.71538 } \\
\text { - ssudah }\end{array}$ & .47231 & .13100 & -1.00080 & -.42997 & -5.461 & 12 & .000 \\
\hline
\end{tabular}

Nilai signifikansi (sig 2-tailed) sebesar 0,000 (nilainya kurang dari $0,05)$ maka kesimpulannya ada perbedaan kadar hemoglobin antara sebelum dan sesudah perlakuan pemberian jus jambu.

Karena signifikansi $<0,05(0,000<0,05)$ maka Ho ditolak. Jadi dapat di simpulkan bahwa ada perbedaan kadar hemoglobin sebelum dan sesudah pemberian jus jambu. Dari rata-rata (mean) dapat diketahui bahwa rata-rata kadar hemoglobin mahasiswi setelah pemberian jus jambu lebih tinggi daripada sebelum pemberian jus jambu. Hal ini dapat diartikan bahwa pemberian jus jambu dapat meningkatkan kadar hemoglobin mahasiswi warga Asrama Mahasiswa Mamba'ul 'Ulum Surakarta.

b. Analisa data statistic pada kelompok kontrol (diberi sirup rendah gula) Tabel 5.Paired Samples Statistics pada sampel pada kelompok kontrol (diberi sirup rendah gula)

Paired Samples Statistics

\begin{tabular}{|c|c|c|c|c|c|}
\hline & & Mean & $\mathrm{N}$ & Std. Deviation & Std. Error Mean \\
\hline \multirow[t]{2}{*}{ Pair 1} & sebelum & 11.6538 & 13 & 1.34884 & .37410 \\
\hline & sesudah & 10.8969 & 13 & 1.27879 & .35467 \\
\hline
\end{tabular}

Dari hasil uji analisis statistik pada sampel kontrol dengan di beri sirup rendah gula sehari 3 kali adalah rata-rata hasil pemeriksaan hemoglobin sebelum diberi sirup rendah gula adalah 11,6538, jumlah sampel data 13, standar deviasi 1.34884, dan standar error mean 0,37410. Sedangkan untuk sesudah diberi sirup rendah gula adalah mean 10, 8969 dengan jumlah sampel 13, standar deviasi 1,27879 dan standar error mean 0,35467 . 
Tabel 6. Paired Sampel Korelasi pada sampel kontrol (diberi sirup rendah gula)

\begin{tabular}{lcccc}
\hline \multicolumn{5}{c}{ Paired Samples Correlations } \\
\\
& N & Correlation & Sig. \\
\hline Pair 1 & sebelum \& ssudah & 13 & .471 & .104 \\
& & & & \\
\hline
\end{tabular}

Pada tabel 6 tersebut menunjukkan besarnya korelasi atau hubungan antara dua sampel sebelum dan sesudah pemberian sirup rendah gula.

Berdasarkan hasil uji korelasi tersebut menunjukkan Signifikansi (sig) $>0,05$, maka tidak terdapat hubungan antara sebelum dan sesudah pemberian sirup rendah gula. Diketahui nilai korelasi sebesar 0,471 dengan signifikansi 0,104. Karena signifikansi $>0,05$ maka dapat disimpulkan tidak terdapat hubungan antara kadar Hemoglobil sebelum dan sesudah pemberian sirup rendah gula.

Sebagaimana dijelaskan sebelumnya jika nilai korelasi semakin mendekati 1,maka hubungannya semakin kuat.Sedangkan jika nilai korelasinya semakin medekati 0 , maka hubungannya semakin lemah (Priyono, 2012). Jadi karena nilai korelasi 0,471 (semakin mendekati 0) maka hubungan yang terjadi adalah lemah (tidak ada hubungan).

Tabel 7. Paired Samples T Test pada sampel pada sampel kelompok kontrol (diberi sirup rendah gula)

\section{Paired Samples Test}

Paired Differences

\begin{tabular}{|c|c|c|c|c|c|c|c|}
\hline & \multirow[b]{2}{*}{ Mean } & \multirow[b]{2}{*}{ Std. Deviation } & \multicolumn{3}{|c|}{$\begin{array}{l}\text { 95\% Confidence } \\
\text { Interval of the } \\
\text { Difference }\end{array}$} & \multirow{2}{*}{\multicolumn{2}{|c|}{$\begin{array}{r}\text { Sig. } \\
(2- \\
\text { df tailed })\end{array}$}} \\
\hline & & & Mean & Lower & Upper & & \\
\hline $\begin{array}{c}\text { Pair } 1 \text { sebelum - } \\
\text { ssudah }\end{array}$ & .75692 & 1.35252 & .37512 & -.06040 & 1.57424 & 2.018 & .067 \\
\hline
\end{tabular}

Nilai signifikansi (sig 2-tailed) sebesar 0,067 (nilainya lebih dari 0,05 ) maka kesimpulannya tidak ada perbedaan nilai hemoglobin pada kelompok kontrol antara sebelum dan sesudah pemberian sirup rendah gula. 
Karena signifikansi $>0,05(0,067>, 0,05)$ maka Ho diterima. Jadi dapat di simpulkan bahwa tidak ada perbedaan kadar hemoglobin sebelum dan sesudah pemberian sirup rendah gula pada kelomok kontrol. Dari rata-rata (mean) dapat diketahui bahwa rata-rata kadar hemoglobin mahasiswi setelah pemberian sirup rendah gula tidak ada perbedaan dari sebelum pemberian sirup rendah gula. Hal ini dapat diartikan bahwa pada pemberian sirup rendah gula tidak dapat meningkatkan kadar

hemoglobin mahasiswi warga Asrama Mahasiswa Mamba'ul 'Ulum Surakarta.

Hasil penelitian menunjukkan dengan pemberian juss jambu 200 ml sehari 3 kali selama 5 hari menunjukkan rata-rata hasil pemeriksaan hemoglobin sebelum diberi jus jambu biji merah adalah 10.7462, jumlah sampel data 13, standar deviasi 1.18927, dan standar error mean 0.32984. Sedangkan untuk sesudah perlakuan pemberian jus jambu biji merah adalah mean 11.4615 dengan jumlah sampel 13, standar deviasi 1.20591 dan standar error mean 0.33446.Nilai signifikansi (sig 2 -tailed) sebesar 0,000 (nilainya kurang dari 0,05) maka kesimpulannya ada perbedaan kadar hemoglobin antara sebelum dan sesudah perlakuan pemberian jus jambu bijimerah. Dari rata-rata (mean) dapat diketahui bahwa rata-rata kadar hemoglobin mahasiswi setelah pemberian jus jambu lebih tinggi daripada sebelum pemberian jus jambu biji merah. Hal ini dapat diartikan bahwa pemberian jus jambu dapat meningkatkan kadar hemoglobin mahasiswi warga Asrama Mahasiswa Mamba’ul ‘Ulum Surakarta.

Hasil penelitian pada kelompok kontrol dengan diberi sirup rendah gula sehari 3 kali adalah rata-rata hasil pemeriksaan hemoglobin sebelum diberi sirup rendah gula adalah 11,6538, jumlah sampel data 13, standar deviasi 1.34884, dan standar error mean 0,37410. Sedangkan untuk sesudah diberi sirup rendah gula adalah mean 10, 8969 dengan jumlah sampel 13, standar deviasi 1,27879 dan standar error mean 0,35467.Nilai signifikansi (sig 2-tailed) sebesar 0,067 (nilainya lebih dari 0,05) maka kesimpulannya tidak ada perbedaan yang signifikan nilai hemoglobin antara sebelum dan sesudah pemberian sirup rendah gula.

Kelompok perlakuan diberi jus jambu biji 150 gram buah jambu biji (Yususf, 2010) buah jambu dengan daging merah, berbentuk bulat, dan kulit berwarna kuning (Wibawa, 2009) ditambah $200 \mathrm{ml}$ air lalu ditambahkan 1 sachet gula rendah kalori, dengan pemberian sebanyak 3 gelas perhari 30 menit sebelum makan (Francisca, 2011) selama 5 hari (Normaida, 2013)

Salah satu buah yang dapat meningkatkan kadar hemoglobin adalah buah jambu biji, kandungan zat kimia dalam jambu biji adalah asam amino (triptofan, lisin), kalsium, fosfor, besi, belerang, vitamin A, vitamin B1, dan vitamin C. Kandungan mineral yang ada dalam buah jambu biji dapat mengatasi penderita anemia (kekurangan darah merah) karena didalam buah jambu biji merah mengandung juga zat mineral yang dapat memperlancar proses pembentukan hemoglobin sel darah merah. 
Kandungan mineral seperti magnesium, tembaga dan mangan.Mangan digunakan oleh tubuh sebagai faktor rekan untuk enzim antioksidan, superoksida dismutase.Tembaga dibutuhkan dalam produksi sel darah merah, hal ini sesuai dengan pendapat Muhlisah (2010).

Sebagaimana penjelasan Cahyono (2010) kandungan gizi dalam 100 gram jambu biji merah adalah : Dalam 100 gram buah jambu biji merah adalah : 36-50 kalori, 77-86 g air, 2,8-5,5 g serat, 0,9-1,0 g protein, 0,1-0,5 g lemak, 0,43-0,7 g abu, 9,5-10 g karbohidrat, 9,1-17 mg kalsium, 17,8-30 mg fosfor, 0,3-0,7 mg besi, 200-400 IU vitamin A, $200-400 \mathrm{mg}$ vitamin C, 0,046 mg vitamin $\mathrm{B}_{1}$, 0,03-0,04 mg vitamin $\mathrm{B}_{2}, 0,6-1,068 \mathrm{mg}$ vitamin $\mathrm{B}_{3}, 82 \%$ bagian yang dimakan.

Vitamin C terdapat dalam bentukasam askorbat maupun dehidroaskorbat. Asam askorbat diabsorpsi usus halus danhampir seluruh asam askorbat dari makanan terabsorpsi sempurna. Vitamin $\mathrm{C}$ bersifat hidrofilik dan berfungsi paling baik pada lingkungan airsehingga merupakan antioksidan utama dalam plasma terhadap serangan radikal bebas (ROS/Reactive Oxygen Species) (Sulistyowati, 2006).

Hal ini juga sejalan dengan pendapat Fathimah dkk (2011) yang menyatakan bahwa konsumsi buah jambu biji sebagai sumber vitamin $C$ dapat membantu meningkatkan penyerapan zat besi, akan tetapi jika asupan vitamin $\mathrm{C}$ rendah, dapat memberikan implikasi terhadap kadar hemoglobin ibu hamil. Kandungan vitamin $C$ yang tinggi pada jambu biji dapat dimanfaatkan oleh ibu hamil untuk pembentukan sel darah merah, karena menurut Departemen Gizi dan Kesehatan Masyarakat (2011) selama kehamilan, konsentrasi vitamin C dalam darah turun akibatnya terjadi hemodilusi sel darah merah.

Dalam buah Jambu biji merah mengandung senyawa yang dapat meningkatkan kadar hemoglobin dalam darah, antara lain : zat besi, vitamin C, vitamin A, tembaga dan fosfor.Zat besi merupakan mineral yang diperlukan untuk mengangkut oksigen ke seluruh tubuh.Kekurangan zat besi dalam tubuh dapat membuat seseorang mengalami penurunan sistem kekebalan tubuh dan sering merasa lesu.Hal ini juga merupakan salah satu penyebab anemia.Zat besi dengan vitamin $\mathrm{C}$ membentuk askorbat besi kompleks yang larut dan mudah diserap oleh organ-organ pada tubuh manusia. Pengubahan zat besi non-heme dalam bentuk senyawa etabolis Ferri menjadi Ferro akan semakin besar bila pH di dalam lambung semakin asam. Vitamin $C$ dapat menambah keasaman sehingga membantu meningkatkan penyerapan zat besi sebanyak 30\% (Sianturi, 2012.

\section{SIMPULAN DAN SARAN}

\section{Simpulan}

Berdasarkan hasil penelitian dapat di ketahui dengan pemberian jus jambu $200 \mathrm{ml}$ sehari 3 kali selama 5 hari adalah berpengaruh pada kadar 
hemoglobin. Nilai signifikansi (sig 2-tailed) sebesar 0,000 (nilainya kurang dari 0,05$)$ maka kesimpulannya ada perbedaan kadar hemoglobin antara sebelum dan sesudah perlakuan pemberian jus jambu. Dari rata-rata (mean) dapat diketahui bahwa rata-rata kadar hemoglobin mahasiswi setelah pemberian jus jambu lebih tinggi daripada sebelum pemberian jus jambu. Hal ini dapat diartikan bahwa pemberian jus jambu dapat meningkatkan kadar hemoglobin mahasiswi warga Asrama Mahasiswa Mamba'ul ‘Ulum Surakarta.

Pada kelompok kontrol dengan di beri sirup rendah gula sehari 3 kali adalah rata-rata hasil pemeriksaan hemoglobin sebelum dan sesudah diberi sirup rendah gula tidak ada perubahan yang signifikan. Nilai signifikansi (sig 2-tailed) sebesar 0,067 (nilainya lebih dari 0,05) maka kesimpulannya tidak ada perbedaan nilai hemoglobin pada kelompok kontrol antara sebelum dan sesudah pemberian sirup rendah gula.

\section{Saran}

Mahasiswa warga asrama mahsiswa Mamba'ul 'Ulum Surakarta. disarankan kepada mahsiswa untuk menjaga asupan makanan yang seimbang dan mengkonsumsi makanan dengan kadarzat besi, vitamin $\mathrm{C}$, vitamin A, tembaga dan fosfor seperti jambu biji merah, sehingga dapat mejaga kadar Hemoglobin. Pengelola Asrama Mamba'ul 'Ulum Surakarta.

disarankan untuk dapat menyediakan bahan makanan yang seimbang yang dapat menjaga kadar Hemoglobin seperti Jus Jambu secara berkala. Peneliti selanjutnya diharapakan penelitian ini dapat di gunakan sebagai dasar penelitian selanjutnya.

\section{DAFTAR PUSTAKA}

Alais, Charles and Guy Linden. 1991. Food Biochemistry. Springer-Science. Perancis

Anonim. 1989. Recommended Dietary Allowances. National Academy Press. Washington DC

Anonim. 2010. Centre for Obesity Research and Education. Monash University. Australia

Cahyono, Bambang. 2010. Sukses Budidaya Jambu Biji di Pekarangan dan Perkebunan. Lily Publisher : Andi. Yogyakarta

Departemen Gizi dan Kesehatan Masyarakat. (2011). Gizi dan Kesehatan Masyarakat. Jakarta : Raja Grafindo Persada.

Fadilah U. N. 2012. Isolasi dan Purifikasi Likopen dari Buah Tomat dan Semangka. Skripsi. Universitas Indonesia. Depok

Frei, B. 1994. Natural Antioxidant in Human Health and Disease. Academic Press. San Diego

Hart, H. 1987. Organic Chemistry A Short Course (6th Edition). Houghton Miffin Company 
Hoffbrand, A. V., J. E. Pettit., dan P. A. H. Moss. 2005. Kapita Selekta Haemotologi. Edisi 4.Jakarta : EGC Penerbit Buku Kedokteran.

Muhilal. 2004. Angka Kecukupan Gizi. Widyakarya Nasional Pangan dan Gizi VIII. Jakarta: LIPI

Muhlisah.(2010). Tanaman Obat Keluarga.Jakarta : Penebar Swadaya. Santoso, MP., Ir. Agus. 2011. SeratPangan (Dietary Fiber) dan Manfaatnya Bagi Kesehatan. Jurnal. Universitas Widya Dharma. Klaten

Sianturi, C. 2012. Pengaruh Vitamin Cpada Penyerapan Zat Besi Non Heme. Medan: FMIPA UNM.

Sulistyowati, Yeny. 2006. Pengaruh Pemberian Likopen Terhadap Status Antioksidan (Vitamin C, Vitamin E dan Gluthathion Peroksidase) Tikus (Rattus Norvegicus Galur Sprague Dawley) Hiperkolesterolemik. Tesis. Universitas Diponegoro. Semarang

Tensiska. 2008. Serat Makanan. Artikel Ilmiah. Universitas Padjadjaran. Bandung 
